Heiki Valk

\title{
ON THE ORIGINS OF CHURCHES AND CHURCHYARDS IN SOUTHERN ESTONIA: THE EVIDENCE FROM EARLY GRAVE FINDS
}

There is almost no written record of the formation of the network of rural churches in medieval Livonia. Although the Chronicle of Henry of Livonia provides information about the two earliest churches in its Latvian part, ${ }^{1}$ the origins of the rural parish churches in Estonia are unknown, except for information regarding the situation that existed around 1240 in the provinces ${ }^{2}$ of Harjumaa and Virumaa in northern Estonia. ${ }^{3}$ Written data about the earliest history of churches are fragmentary and vary in character, being limited to the first

DOI: https://doi.org/10.12697/BJAH.2017.13.06

This research was supported by the Ministry of Education and Science: Scheme IUT-20-7. The author expresses his gratitude to Anu Kivirüüt (National Heritage Board) for reviewing the cremated bone fragments, to Maria Smirnova and Jaana Ratas for work with the illustrations and to Tõnno Jonuks for kind permission to publish photos of unpublished finds from Paistu churchyard from the excavations of 2016.

Abbreviations: AI - Archaeological collections and archives of Archaeological Research Collection, University of Tallinn; ERM - Collections of Estonian National Museum; ÕES - Archaeological collections of the Learned Estonian Society (Gelehrte Estnische Gesellschaft), presently in the archaeological collections of the University of Tartu; SbGEG - Sitzungsberichte der Gelehrten Estnischen Gesellschaft, Dorpat; TÜ - University of Tartu and its archaeological collections; TaM Collections of former Tartumaa Museum (presently Estonian National Museum); TM - Collections of Tartu City Museum; VaM - Collections of Valga Museum; ViM - Collections of Viljandi Museum.

1 Henriku Liivimaa kroonika. Heinrici Chronicon Livoniae, transl. by Richard Kleis, ed. by Enn Tarvel (Tallinn: Eesti Raamat, 1982), I: 3, 6; II: 2. See also: Kersti Markus, "Liivimaa kristianiseerimine visuaalkultuuri vaatevinklist", Tuna, 2 (2014), 10-20.

2 In the present article the word province is used to designate prehistoric provinces, district for historical and cultural areas of the $19^{\text {th }}$ century, and county for present-day administrative units.

3 Paul Johansen, Die Estlandliste des Liber Census Daniae (Reval: Wassermann, 1933). 
mentions of either the parish, the priest or the church. ${ }^{4}$ Essential information can be provided by the architectural evidence that can indicate an earlier origin of the church than is known from other sources. In addition, information about the construction of parish churches and the reasons for choosing the sites can also be provided by archaeological record, including grave finds in churchyard. Since, in most cases, there is little architectural and written data on the earliest history of the medieval churches in southern Estonia, the contribution of archaeological evidence should not be underestimated.

In medieval Western Europe, burial in the consecrated ground of a churchyard was the only normal burial for a Christian. Although burials inside the churches did not occur for a long time - according to Decretum Gratiani, a collection of letters of Pope Gratianus from ca. 1140, it was allowed only for the clergy and "especially religious laymen" 5 - it became a common practice in the $13^{\text {th }}$ century. During the Crusades, burying the dead in churchyards was also introduced in Livonia where cemeteries existed in all the churchyards of the parish churches. However, the written data does not reveal the reasons for choosing a definite site for a church and churchyard.

The aim of this article is to shed some light, based on archaeological data, on the earliest history of the cemeteries in churchyards in southern Estonia, the diocese of the Bishop of Tartu - an area about the medieval churches of which systematic research in terms of architectural history has been undertaken by Kaur Alttoa since the 1970s. ${ }^{6}$ The text presents information about the grave finds from churchyards and churches related to both prehistory, mostly its

4 Enn Tarvel, "Sakala ja Ugandi kihelkonnad", Keel ja Kirjandus, 9 (1968), 543-550; Keel ja Kirjandus, 10 (1968), 586-596.

5 Per Kristian Madsen, "Han ligger under en blå sten. Om middelalderens gravskik på skrift og i praksis", Hikuin, 17 (1990), 116-119.

6 E.g. Kaur Alttoa, "Halliste keskaegsest kirikuhoonest", Kunstiteadus. Kunstikriitika, 5 (Tallinn: Kunst, 1983), 133-146; Kaur Alttoa, "Nõo Laurentsiuse kirikust", Kunstiteaduslikke Lurimusi, 7 (Tallinn: Eesti Kunstiteadlaste Ühing, 1994), 231-244; Kaur Alttoa, "Märkmei doctissimo et expertissimo (Tallinn: Eesti Muinsuskaitse Selts, 1995), 65-84; Kaur Alttoa, Lõuna-Eesti arhitektuur 15. saj.-16. saj. I poolel. Master's thesis (Tartu: Tartu Ülikool, 1995) Manuscript in the library of the University of Tartu; Kaur Alttoa, "Keskaegsest Kambja kirikust", Wastne Testament 1686 (Tartu: B. G. Forseliuse Selts, 1996), 76-80; Kaur Alttoa, Tartu Jaan kirik (Tallinn: Muinuskaitseamet, 2011); Kaur Alttoa, Die Kirche zu Urbs/Urvaste und die Frage der Rigenser Bauschule im 13. Jahrhundert", Baltic Journal of Art History, 6 (2013), 7-46; Kaur Alttoa, "Tartu Toomemăgi keskajal", "Liivimaa vồmsaim katedraal. Tartu toomkiriku ehituslugu", Tartu toomkiriku kaheksa sajandit. Katedraal. Raamatukogu. Muuseum (Tart Ulikooli Muuseum, 2017) [forthcoming]. final stage, (in archaeological terms, the Final Iron Age, ca. 10501225 AD), and major part of the medieval period, - until ca. 1450 AD. Jewellery from the rural cemeteries of southern Estonia from the Christianization until that time can quite clearly be distinguished as belonging to a definite period. ${ }^{7}$ The existing evidence is mostly scanty and fragmentary, represented by stray finds from disturbed graves with no definite context, and comprised mainly of jewellery and clothing accessories, as well as by human bones, including some cremated fragments.

\section{DATA ACCUMULATION AND RESEARCH HISTORY}

Archaeological finds from the churchyards of southern Estonia started to be collected in the $19^{\text {th }}$ century. This was related to the reconstruction and expansion of medieval churches - accompanied by an emerging interest in antiquities and the birth of archaeology. The construction work that provided archaeological finds occurred in Põlva in 1841, in Palamuse in 1868 (ÕES 758: 1-4), in Kursi (ÕES 1036) and in Võnnu in 1870 (ÕES 962; VM 75; SbGEG 1870, 74), in Kambja in 1878 (ÕES 1091: 1-7), in Maarja-Magdaleena in 1885-1887 (ÕES 1905: 1-4; SbGEG 1895, 53), in Kolga-Jaani in 1873 (ÕES 1110), and in Äksi in 1887-1889 (ÕES 1696; 1700; 1701; SbGEG 1888, 101-102). Finds from the Tarvastu churchyard, collected when the church was reconstructed in 1893 (ÕES 1861a: 1-49; 1861b: 1-128: 1861c: 1-36) should be specially noted as the largest group, comprising over 200 items. Numerous pieces of jewellery were found between long brick walls discovered under the church floor. ${ }^{9}$ The churchyard in Rõngu also provided a large collection when the medieval church was totally rebuilt in 1901 (ÕES 2256: 1-62)..$^{10}$

7 Heiki Valk, Rural Cemeteries of Southern Estonia 1225-1800 (Tartu: Gotland University College, Centre for Baltic Studies; University of Tartu, Archaeology Centre, 2001), 42.

8 Probably, also the find assemblage from the Nõo churchyard (AI 2500: 1-12), deposited in the 1920 s by the Learned Estonian society to the archaeological collections of Tartu University without any more information about its finding circumstances, was gained during some $19^{\text {th }} \mathrm{or}$ early $20^{\text {th }}$ century construction work. See. Uno Plank, chapter from "Noo Kihelkonna ajalugu" [1935], Rahutegija, EELK Nõo Püha Laurentsiuse koguduse sõnumileht, 3 (2007), 1-2. See: http://nookirik.ee/wp-content/uploads/Nr-3-juuli-2007.pdf [viewed 15.07.2017].

9 Michael Jürmann, Tarvastu kiriku mälestusteraamat (Tartu: Hermann, 1901), 35 .

10 See also Richard Hausmann, "Ueber Alterthümer gefunden auf dem Hofe der Kirche zu Ringen”, Sitzungsberichte der Gelehrten Estnischen Gesellschaft 1901 (Dorpat, 1902), 129-137. 
Between the 1920s and the 1970s, no major construction work was undertaken in the rural medieval churches of southern Estonia: the expansions of the church buildings made in the $19^{\text {th }}$ century were able to satisfy the needs of the 1920s and 1930s. The only finds from this time are those from Otto Freymuth's research excavations at the Palamuse Church in 1929 (AI 2699: 1-3). World War II and the decades of Soviet rule that followed did not favour church life and no major construction or development activities were undertaken in the rural churches. Since that time, the grave finds that should be mentioned include those from the local Palamuse club in the former churchyard area in the 1950s (TaM A 111-128), from the earthworks in the Rannu churchyard in 1959 (ERM A 565: 11-13) and from Nõo churchyard (TaM Aj 58: 1-5). Bones were also found when a gas heating system was installed in the sacristy of the Kolga-Jaani Church in 1972.11

During the final stage of the Soviet period, there were two parallel trends related to the medieval churches of southern Estonia: 1) the reconstruction of some ruined or deserted buildings, 2) conducting and developing professional architectural history research. In the late 1970s and early 1980s, systematic research was undertaken at the Tartu Cathedral. ${ }^{12}$ The church in Halliste, which burned down in 1959, was rebuilt in 1989-1991, and research monitoring in 1978 revealed the remains of a medieval church building. ${ }^{13}$ Similar work was undertaken in St John's Church in Viljandi in 1987. Research inside and around the foundations of St John's Church in Tartu in 1981, 19831984, 1988-1990, and 1992-1994 in connection with reconstruction work $^{14}$ gave information not only in terms of architectural history, ${ }^{15}$ but a number of graves were also excavated. In 1987, trial pits at Urvaste Church, which were dug to study its construction history, ${ }^{16}$ also provided some artefacts from graves (TÜ 708: 1-9).

Since the late 1980s, simultaneously with the birth of medieval archaeology, churchyards and grounds inside medieval churches

11 AI, f 1: 37: miscellanea, letter by A. Melso (1972).

12 Alttoa, "Liivimaa võimsaim katedraal. Tartu toomkiriku ehituslugu".

13 Alttoa, "Halliste keskaegsest kirikuhoonest".

14 Romeo Metsallik, "Tartu arheoloogilisest uurimisest", Tartu arheoloogiast ja vanemas ehitusloost. Artiklite kogumik, ed. by Heiki Valk. Tartu Ülikooli Arheoloogia Kabineti Toimetised, 8 (Tartu: Tartu Ülikooli arheoloogia kabinet, 1995), 22-23.

15 Alttoa, Tartu Jaani kirik.

16 Work was conducted by Kaur Alttoa have come under protection as archaeological monuments. Since that time, earthworks in churches and churchyards, e.g. digging trenches for water pipelines and electricity cables, have had to be accompanied by archaeological research. At Kambja Church, archaeological investigations took place in the western part of the nave, which was to accommodate an underground cloakroom, in 1993 (Heiki Valk) and 1994 (Ken Kalling: TÜ 501: 1-108.). In addition, information was gained when communication trenches were dug in the churchyard in 1998 (Andres Tvauri: TÜ 709: 1-33). Minor rescue or monitoring work has taken place at several churches: in Pilistvere in 199917; in Nõo in 1998 (Tõnno Jonuks, Andres Tvauri) and 2015 $5^{18}$; in Paistu in 2001 and 2016 ${ }^{19}$; in Puhja in 2004 and in Kursi in 2016 (both Peeter Piirits) and in Rõngu in 2017 (Rivo Bernotas). ${ }^{20}$ Archaeological research at urban sites was undertaken at the cemetery of St John's Church in Viljandi in 1990 (Heiki Valk), at St Mary's churchyard in Tartu in 2010 and 201121, as well as at the Tartu Cathedral in 1986, 1987, 2001, 2002, 2008, 2013 and 2017. ${ }^{22}$ The results of archaeological work, as well as earlier stray finds, form the main body of information about the early history of the cemeteries in the churchyards of southern Estonia, and first preliminary conclusions can be drawn thereupon.

17 Heiki Valk, "Archaeological Investigations in Late Prehistoric - Early Medieval Viljandi and in Pilistvere Churchyard", Archaeological Field Work in Estonia / Arheoloogilised välitööd Eestis 1999 (Tallinn: Muinsuskaitseinspektsioon, 2000), 50-51.

18 Martin Malve, "Archaeological fieldwork at the Medieval and Early Modern churchyards in Nõo, Pilistvere and Põltsamaa", Archaeological Field Work in Estonia / Arheoloogilised välitööd Eestis 2015 (Tallinn: Muinsuskaitseinspektsioon, TLÜ, TÜ, 2016), 199-210.

19 Marge Konsa, "Archaeological investigations in the churchyard of Paistu", Archaeological Field Work in Estonia / Arheoloogilised välitööd Eestis 2001 (Tallinn: Muinsuskaitseamet, 2002), 60-164; Martin Malve, Taisi Juus, "Matused Paistu kirikaiast", Tutulus. Eesti Arheoloogi aastakiri (Tartu: Tartu Ülikool, 2016), 38-39.

20 In 2014 when, the ground under the floor was removed from the entire inside of the Puhja Church to a level of 20 to $30 \mathrm{~cm}$ above the burials, the work did not result in any artefacts. No

21 Martin Malve, Raido Roog, Andres Tvauri, "Preliminary Results of the Rescue Excavation in St Mary's Churchyard and its Surroundings in Tartu 2010-2011", Archaeological Field Work 137-150. A new survey about the results of these excavations will be published by Elis Tidu in he Tartu City Museum jearbook (Turtur Linnamusermi aastaraamat) 2017.

22 Heiki Valk, "Tartu Toomkiriku kalmistust", Tartu arheoloogiast ja vanemast ehitusloost. Artiklite kogumik, ed. by Heiki Valk. Tartu Ülikooli Arheoloogia Kabineti Toimetised, 8 (Tartu: Tartu Ülikool arheoloogia kabinet, 1995), 59-80; Heiki Valk, "Tartu Toomkirik ja kirikaed kui kalmistu”, Tartu toomkiriku kaheksa sajandit. Katedraal. Raamatukogu. Muuseum (Tartu Ülikooli Muuseum, 2017) [forthcoming]. 


\section{THE GENESIS OF PARISH CHURCHYARDS}

The earliest data about the formation of the network of parish churches in southern Estonia originate from the Chronicle of Henry of Livonia. Saccala (Sakala) and Ugaunia (Ugandi) (up to the Emajõgi River) were baptized in $1215,{ }^{23}$ and the first wooden churches were constructed soon after it. In the context of the uprising of 1223, Henry notes that the Estonians exhumed the bodies of their deceased from the Christian cemeteries and buried them according to the pagan custom; ${ }^{24}$ after the uprising the churches were rebuilt. ${ }^{25}$ Data related to the Gauja and Metsepole Livs from 1207 and $1211^{26}$ also confirm the presence of churches and churchyards soon after baptism. Burials in the churchyard could begin even before the construction of the church - after selecting and consecrating the area. ${ }^{27}$

The first parish churches were made of timber. Currently, the only information about them from southern Estonia is related to the remains from the inside of the nave of St John's Church in Tartu. ${ }^{28}$ The building, made of ca. $20 \mathrm{~cm}$ thick $\operatorname{logs}$, was at least $5.4 \mathrm{~m}$ wide and had a wooden floor made of ca. $30 \mathrm{~cm}$ wide boards; there were graves on its exterior, but no burials were discovered inside. Possible parallels to the primary wooden churches of the early $13^{\text {th }}$ century may be provided by finds from Finland, especially from its earliest church site at Ravattula Ristimäki in Kaarina parish near Turku, which was excavated between 2013 and 2016. ${ }^{29}$ The location of the $9.5 \mathrm{~m}$ long and $6 \mathrm{~m}$ wide timber church, with a quadrangular choir measuring ca. $4 \times 3.5 \mathrm{~m}$, was indicated by the stone foundations for the walls, as well as the remains of the altar.

23 Henriku Liivimaa kroonika, XIX: 4, 7

24 Ibidem, XVI: 8.

25 Ibidem, XXIX: 1

26 Ibidem, XI: 5; XIV: 10.

27 Bertil Nilsson, De sepulturis. Gravrätten i Corpus Iuris Canonici och i medeltida nordisk lagstiftning. Bibliotheca Theologiae Practicae. Kyrkovetenskapliga studier, 44 (Stockholm: Almquist \& Wiksell International, 1989), 73-75.

28 Metsallik, "Tartu arheoloogilisest uurimisest", 22-23; Alttoa, Tartu Jaani kirik, 11-12.

29 Juha Ruohonen, "Built of Wood and Turned to Soil: Perspectives of Research History and New Observations Concerning Finland's Oldest Churches with Reference to Ristimäki in Ravattula", New Sites, New Methods, ed. by Pirjo Unno, Kerkko Nordqvist. Proceedings of the Finnish-Russian Archaeological Symposium Helsinki, 19-21 November 2014 (Helsinki: Suome Muinaismuistoyhdistys, 2016), 229-245.

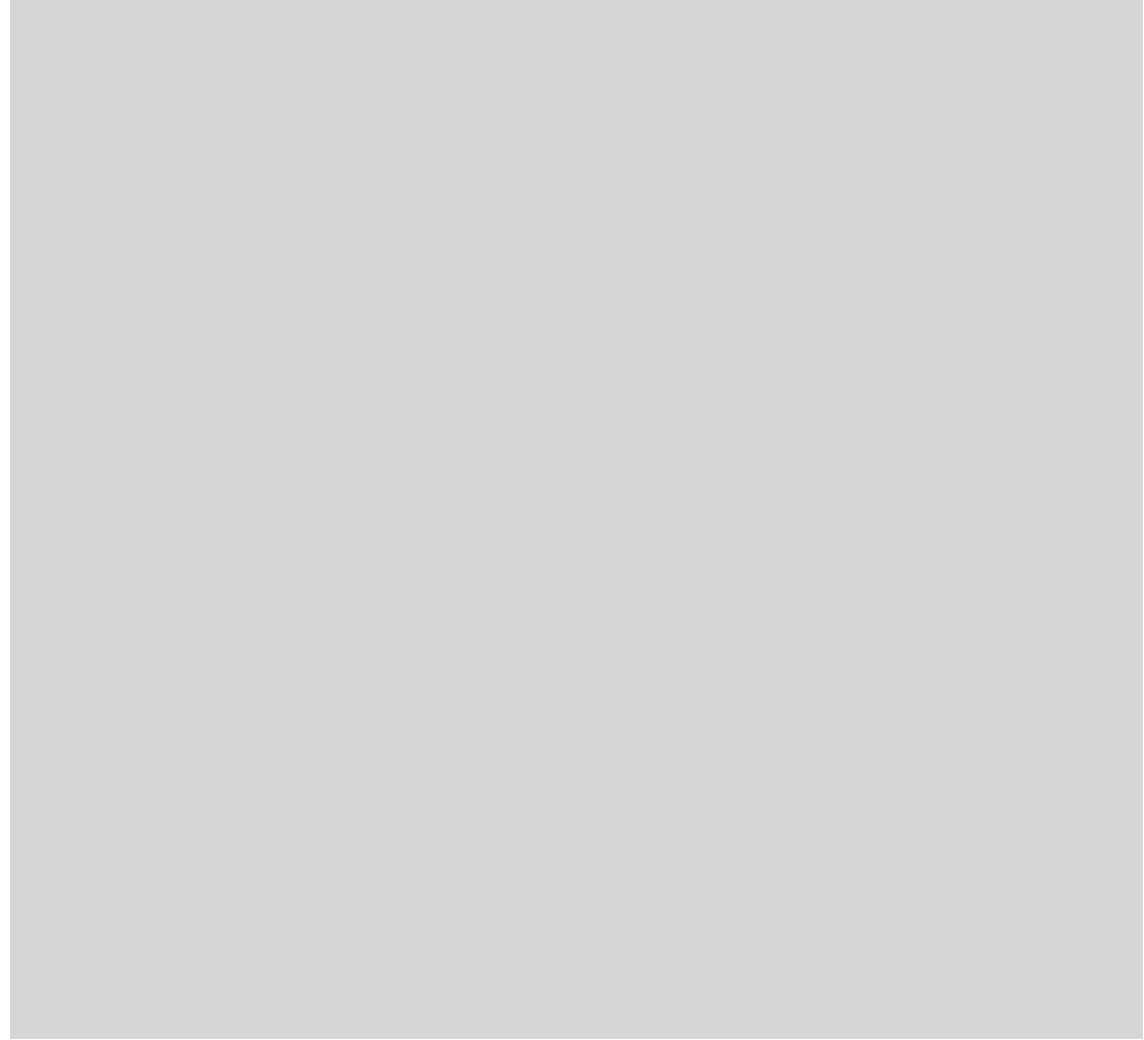

Fig. 1. Cemetery finds from the churchyards of southern Estonia from before ca. $1450 \mathrm{AD}$ 1 - finds of cremated bones;

2 - Final Iron Age jewellery with traces of fire

3 - Final Iron Age uncremated jewellery;

4 - finds from ca. $1225-1450$;

5 - medieval churches with no medieval grave finds,

6 - parish churches of post-medieval origin;

- conventional northern border of southern Estonia.

Graphics by Maria Smirnova.

\section{ARCHAEOLOGICAL EVIDENCE}

Data about finds from the graves in the churches and churchyards of southern Estonia (Fig. 1) come from the lands ruled by the Teutonic Order in southwest Estonia and the Bishopric of Tartu. Within the bishopric, the northern and southern part of the historical district of Tartumaa, separated by the Emajõgi River, and the culturally defined district of Võrumaa can be regarded 


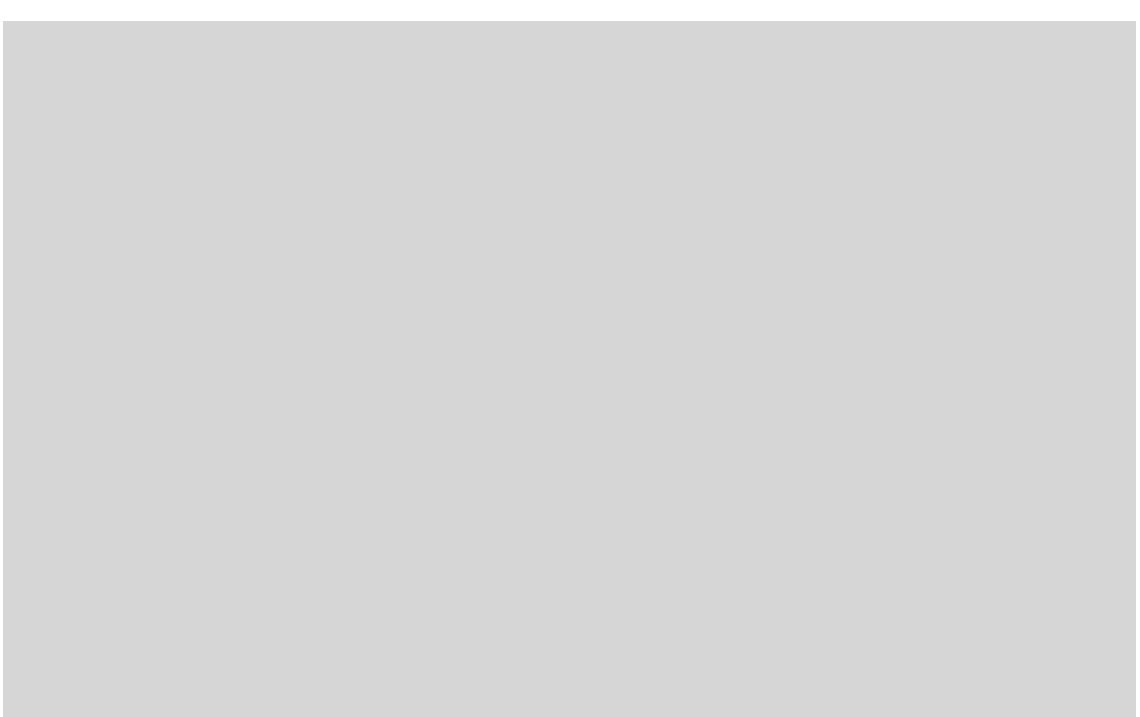

Fig. 2. Finds from Kolga-Jaani churchyard (ÕES 1110: 5, 3, 14, 7, 1, 6, 8). 1- belt buckle 2 - bells; $3,4,6$ - brooches; 5 - bracelet; 7 - ring with traces of fire. Photo: Heiki Valk.

as separate geographic units. The following survey presents data within the framework of these areas, related primarily to sites with prehistoric evidence.

Lands of the Teutonic Order. Data from rural churchyards of southern Estonia is quite numerous from the Teutonic lands, which mainly corresponded to the present-day Viljandi County. In Pilistvere, where a priest was first mentioned in $1234,{ }^{30}$ the stone church dates back to the third quarter of the $13^{\text {th }}$ century. ${ }^{31}$ The Iron Age origin of the cemetery in the churchyard is demonstrated by numerous fragments of cremated bones (TÜ 802; TÜ 818: 27, $33,40,48)$. The cremains are mostly dark, partly grey or black in colour, which refers to their origin as being from the later stages of prehistory. However, in some cases also white, calcined cremains referring to possible earlier burials were found. Two spiral tubes and a chain fragment (TÜ 818: 5-6, 35), all of bronze, may also date back to the late prehistoric age. Hand-moulded pottery, including

30 Hermann Hildebrand, Livonica, vornämlich aus dem 13. Jahrhundert im vatikanischen Archiv (Riga: J. Deubner, 1883), 49.

31 Alttoa, Lõuna-Eesti arhitektuur 15. saj.-16. saj. I poolel, 18 from the Viking Age (TÜ 818: 29-31, 37), and a tiny trapezoid bronze pendant (TÜ 818: 34) may both originate from the Iron Age cemetery, or from occupation layers from that time. A round brooch (TÜ 818: 3) dates from the $13^{\text {th }}-14^{\text {th }}$ centuries.

In Kolga-Jaani, the stone church may date from the first half of the $14^{\text {th }}$ century. ${ }^{32}$ Most of the finds (ÕES 1110: 1-14), including two wire bracelets $(2 \times 2)$ with twisted loop ends, small bells, a penannular brooch with knob-shaped ends and round brooches, date back to the $13^{\text {th }}$ and $14^{\text {th }}$ centuries (Fig. 2). The prehistoric origin of the cemetery is suggested by cremated bone fragments found near the church wall at a depth of $40-50 \mathrm{~cm}$, as well as by the fragment of a two-part bronze buckle (Fig. 2: 1). ${ }^{33}$ A spiral ring with supposed traces of fire (Fig. 2: 7) may also date from the $13^{\text {th }}$ century.

In Halliste where the parish is first mentioned in $1504{ }^{34}$ the stone church was probably built in the $2^{\text {nd }}$ half of the $15^{\text {th }}$ century. ${ }^{35} \mathrm{~A}$ possible Iron Age cemetery is indicated by cremated bone fragments found in 1991 in the churchyard, $20 \mathrm{~m}$ south of the southern portal, in the disturbed ground of a water pipeline trench (TÜ 41). Cremated bones, together with handmade pottery, including fragments with striated surfaces that are typical of the first half of the first millennium AD (TÜ 970), were also found in the field immediately behind the churchyard, north of the church tower, from the area measuring $50 \times 80 \mathrm{~m}$. Both groups of finds refer either to fully destroyed stone graves or flat cremations. Most likely, considering the distance of places where they were found, the cremains originate from two different cemeteries, and may be from different time. Data about graves inside the church are limited to information about a large and compact group of re-buried bones found under the church floor in the part of the choir closest to the altar. ${ }^{36}$

32 Alttoa, Lõuna-Eesti arhitektuur 15. saj--16. saj. I poolel, 22

33 Similar buckles occur in several late $12^{\text {th }}$ and early $13^{\text {th }}$ century graves at Pada Cemetery in Virumaa (e.g. graves no. I, XXVII, LI)

34 Livländische Güterurkunden (aus den Jahren 1501 bis 1545), Bd. II, ed. by Hermann von Bruiningk (Riga: Gulbis. 1923), no. 37

35 Alttoa, "Halliste keskaegsest kirikuhoonest"; Alttoa, "Märkmeid Lõuna-Eesti keskaegsetes maakirikutest", 146

36 Oral data from Ago Liibek, supervisor of the church reconstruction work. 


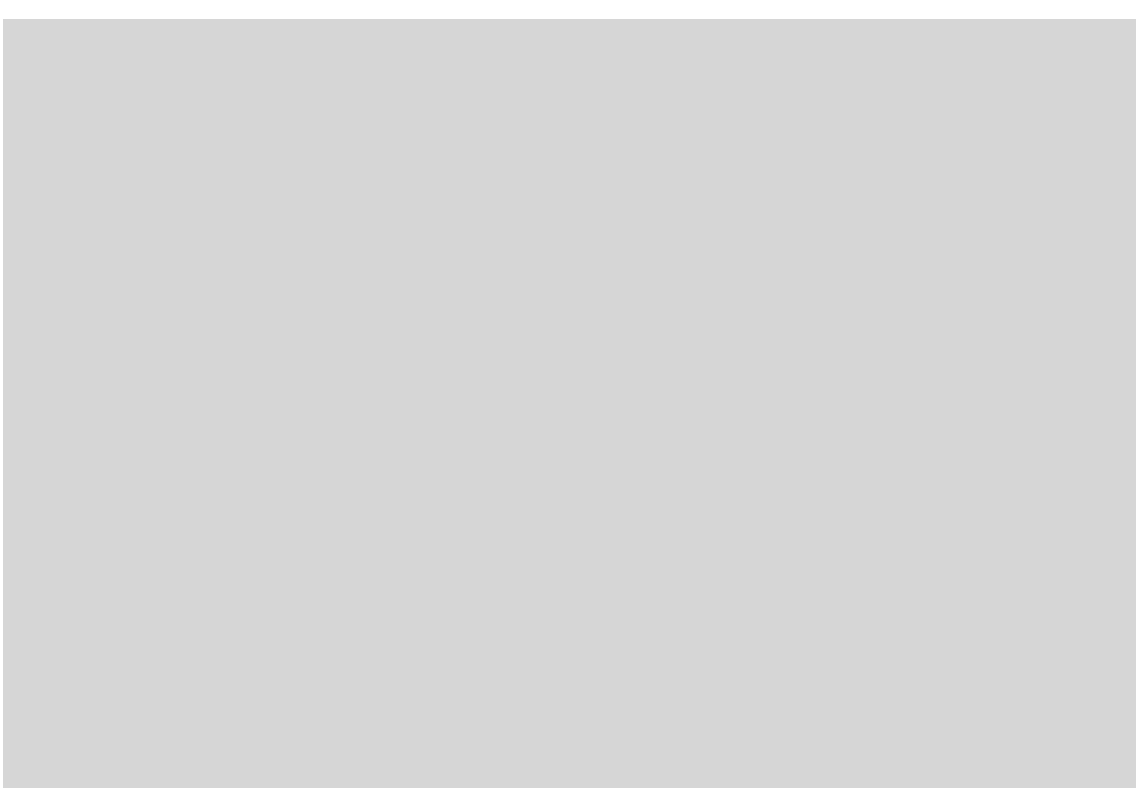

Fig. 3. Finds from Paistu churchyard. 1, 2 - penannular brooches (silver); 3, 5 - brooches; 4 - sheet pendant (silver); 6 - beads; 7 - cowry shells (TÜ 2613: 2; TÜ 999: 8; TÜ 2613: 13, $12,32,15,14)$. Photo: Heiki Valk.

The stone church in Paistu, where a priest was first mentioned in $1234,{ }^{37}$ may date from the last quarter of the $13^{\text {th }}$ century; ${ }^{38}$ and the church itself is mentioned in $1329 .{ }^{39}$ Finds from rescue excavations ${ }^{40}$ (TÜ 999: 1-23; TÜ 2613: 1-33) are of medieval origin, often from the $13^{\text {th }}-14^{\text {th }}$ century (Fig. 3). The two silver finds - a penannular brooch (Fig 3: 2) and a large sheet pendant (Fig. 3: 4), attest to the higher social status of the peasants buried in the churchyard - such finds do not occur on ordinary village cemeteries of southern Estonia. In 2001, cremated bones and hand-moulded pottery (TÜ 999: 23) were discovered in the churchyard, which also indicates an Iron Age cemetery. The fact that the site was in use in the mid- $13^{\text {th }}$ century

37 Hildebrand, Livonica, vornämlich aus dem 13. Jahrhundert im vatikanischen Archiv, 48 Leonid Arbusow, Steffenhagen, 1913), 315 .

38 Alttoa, "Märkmeid Lõuna-Eesti keskaegsetest maakirikutest", 69; Alttoa, Lõuna-Eesti arhitektuur 15. saj.-16. saj. I poolel, 24.

39 Sulev Vahtre, Liivimaa Noorem Riimkroonika (1315-1348) / Bartholomeus Hoeneke (Tallinn: Eesti Riiklik Kirjastus, 1960), 103.

40 Konsa, "Archaeological investigations in the churchyard of Paistu"; Malve, Juus, "Matused Paistu kirikaiast".

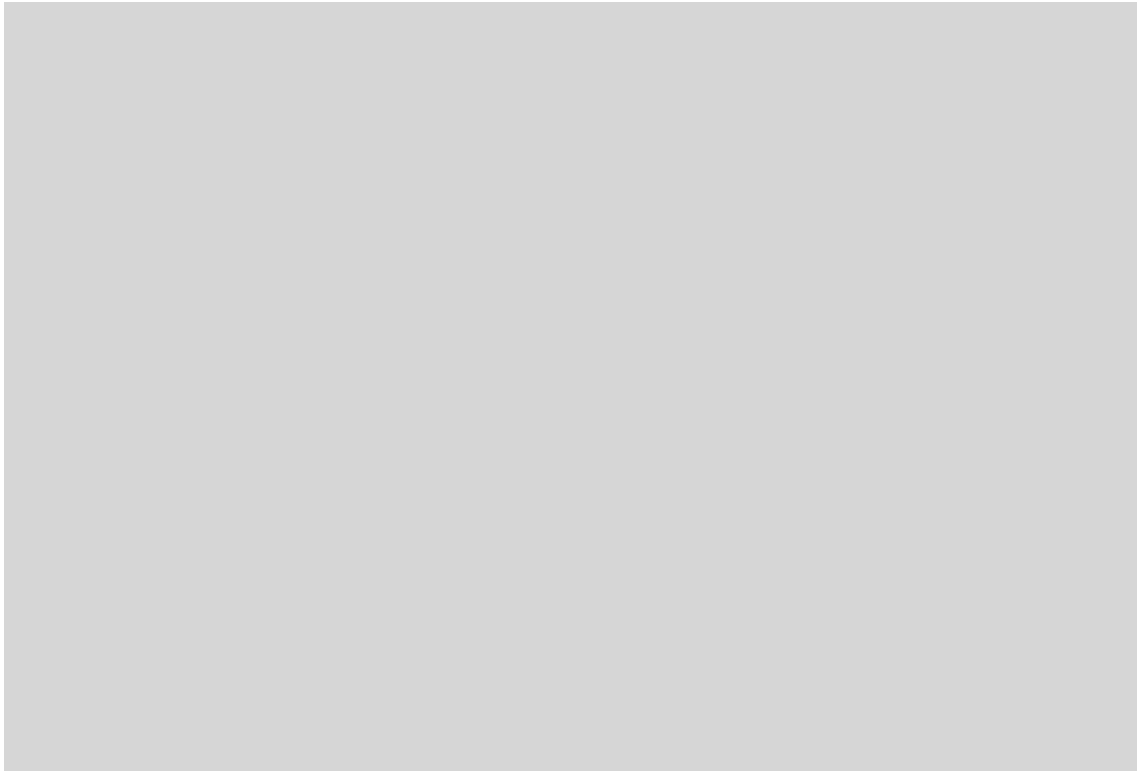

Fig. 4. The church in Tarvastu. Photo: Juhan Maiste.

is confirmed by fragments of wheel-thrown pottery (TÜ 999: 2), identical to those found in the mid- $13^{\text {th }}$ century layers in Viljandi's Pikk Street. ${ }^{41}$

The church in Suure-Jaani was built of stone already in the mid$13^{\text {th }}$ century, ${ }^{42}$ although the parish is not mentioned until $1428 .{ }^{43}$ A fragment of a breast chain of bronze ${ }^{44}$ has been found in the churchyard. Such jewellery may originate from the Final Iron Age, or as late as the mid- $13^{\text {th }}$ century. As the Lõhavere hill fort, one of the two main centres of the Saccala province, is only $3 \mathrm{~km}$ away, and as a priest was present there in $1212,^{45}$ the first, wooden church was probably built in Suure-Jaani soon after the baptism of Saccala in 1215.

41 Heiki Valk, "About the Role of the German Castle at the Town Genesis Process in Estonia: the Example of Viljandi", Castella Maris Baltici 1 (Stockholm: Almquist \& Wiksell International, 1993)

42 Alttoa, Lõuna-Eesti arhitektuur 15. saj.-16. saj. I poolel, 20.

43 Die evangelisch-lutherischen Gemeinden in Russland. Eine historisch-statistische Darstellung, Bd. II (St. Petersburg: Watsar, 1911), 280.

44 Oral data by Evald Tõnisson (1990).

45 Henriku Liivimaa kroonika, XV: 9. 


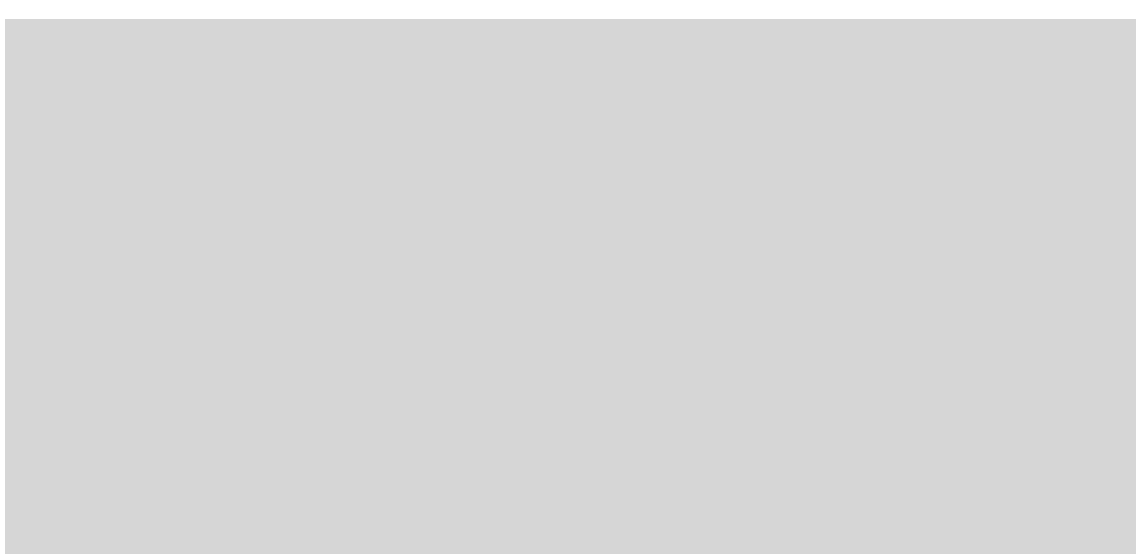

Fig. 5. Bracelets and rings from Tarvastu churchyard (ÕES 1861b: 20, 21, 28-30, 46, 52, 38, 35). Photo: Heiki Valk.

The largest assemblage of finds from the area of prehistoric Saccala comes from Tarvastu where the church caught fire when it was struck by lightning, and then reconstructed and expanded in 1893 (Fig. 4). The parish of Tarvastu was probably recorded already in 1225 when "the first parish found at Lake Võrtsjärv" is mentioned; the first information about a priest is from $1234 .{ }^{46}$ Although the medieval parts of the church probably date from the $2^{\text {nd }}$ half of the $15^{\text {th }}$ century, ${ }^{47}$ the earliest finds from the churchyard are artefacts typical of the Final Iron Age, but which are missing in medieval village cemeteries - a spiral ring with broad middle coil (Fig. 5: 6) and a brooch made of a Final Iron Age chain-bearer (ÕES 1861a: 46). Such rings were numerous in Final Iron Age Estonia ${ }^{48}$ but do not occur in medieval village cemeteries. The chain-bearer, used as a brooch, has an analogue in a late pre-Christian inhumation grave in Tammiku cemetery (Virumaa). ${ }^{49}$ Numerous finds from the $13^{\text {th }}-15^{\text {th }}$ centuries include bracelets, spiral and shield-shaped

46 Henriku Liivimaa kroonika, XXIX: 3; Hildebrand, Livonica, vornämlich aus dem 13. Jahrhundert im vatikanischen Archiv, 48; Arbusow, Livlands Geistlichkeit vom Ende des 12. bis ins 16. Jahrhundert, 316.

47 Alttoa, "Märkmeid Lõuna-Eesti keskaegsetest maakirikutest", 69-70.

48 Jüri Selirand, Eestlaste matmiskombed varafeodaalsete suhete tärkamise perioodil (11.-13. sajand) (Tallinn: Eesti Raamat, 1974), 173, Plate XL: 6; Heiki Valk, Silvia Laul, Siksälä kalme I. Muistis ja ajalugu (Tartu: Tartu Ülikool, Ajaloo ja arheoloogia instituut, arheoloogia osakond, 2014), 69, Fig. 40: 2.

49 Evald Tõnisson, "Das jungeisenzeitliche Gräberfeld Tammiku in Ostestland", Suomen Muinaismuistoyhdistyksen Aikakauskirja, 75 (Helsinki, 1973), 241-242, Fig. 3: 9.

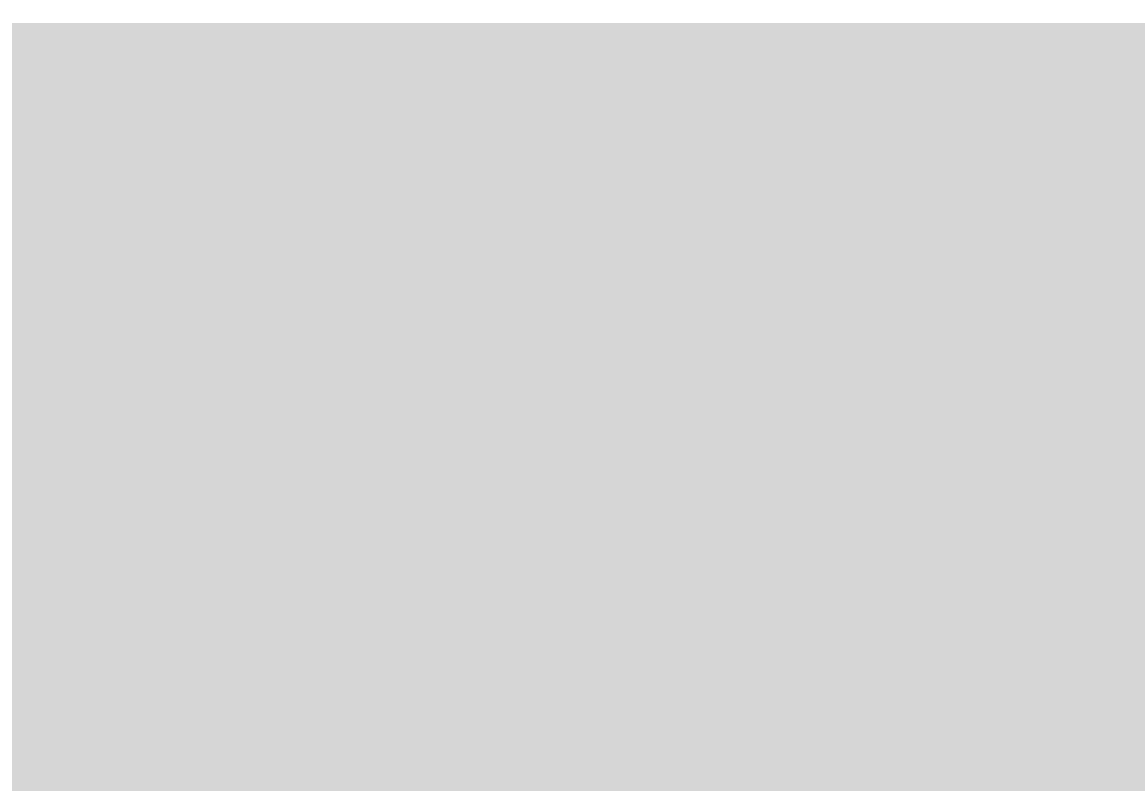

Fig. 6. Finds from Tarvastu churchyard (ÕES 1861a: 49, 44, 42; ÕES 1861b: 92, 94, 76, 79; ÕES 1861a: 47). 1, 2, 3, 9 - brooches; 4, 5, 6- pendants; 7, 8 - bells. Photo: Heiki Valk.

rings (Fig. 5), brooches, small bronze bells, round and rhomb-shaped pendants (Fig. 6), necklaces of cowry shells and beads (Fig. 7). The group of iron artefacts is comprised of only two knives. Most likely, rusty iron objects were not considered attractive enough to be picked up for archaeological collections. The lack of finds with traces of fire, considering the large number of artefacts, allows one to suggest that the cemetery was founded after Christianization, but quite soon thereafter, since the jewellery that went out of fashion in medieval times was still in use.

In Viljandi there were two medieval churches - the main church of St John and St Clara on the market square ${ }^{50}$ and the Church of St John, reconstructed for the needs of the Franciscan monastery from an earlier, minor sanctuary in 1466-1472. The excavations of 1996 at the main church, ${ }^{51}$ which in medieval times evidently also served the rural parish, were too small to date the building. Judging by

50 "Viljandi linn 1599. aastal", transl. by Katrin Vabamäe, annotated by Kaur Alttoa, Viljandi Muuseumi Aastaraamat 1998 (Viljandi: Viljandi Muuseum, 1999), 114.

51 Heiki Valk, "Archaeological investigations in Viljandi, Tartu and Kärkna", Stilus. Eest Arheoloogiaseltsi väljaanne, ed. by Ülle Tamla (Tallinn: Eesti arheoloogiaselts, 1997), 130. 


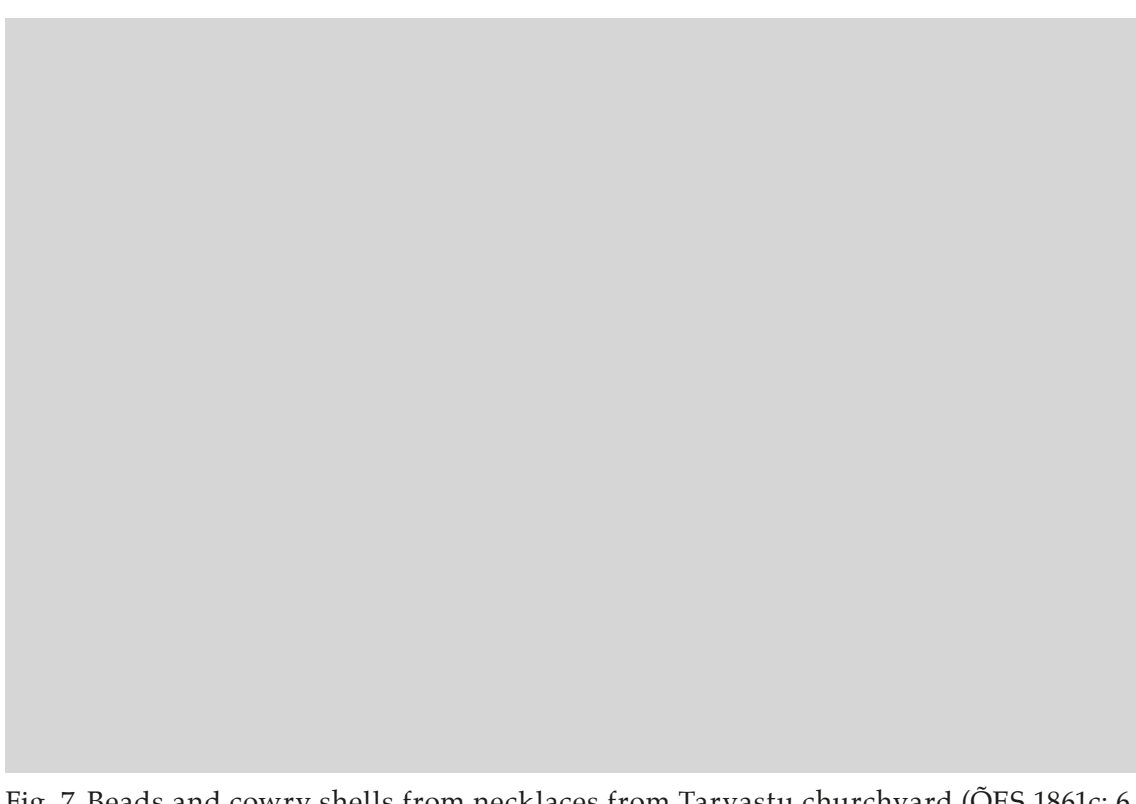

Fig. 7. Beads and cowry shells from necklaces from Tarvastu churchyard (ÕES 1861c: 6 4, 3). Photo: Heiki Valk.

their character, the intensive $13^{\text {th }}$ century occupation layers around St John's Church investigated in 1990 indicate that, until ca. 1300 AD, the area functioned as the earliest market of the medieval town. The cemetery of the first church, the round apsis of which is exhibited in the cellar of the present-day church building, but probably also the church itself, did not exist until that time.

No artefacts have been found in the medieval parish churchyards of Põltsamaa, Helme and Saarde. In Saarde the medieval church $^{52}$ was located northeast of the Jäärja Manor and in Põltsamaa near the Põltsamaa Manor. In Karksi there was probably no medieval parish centre ${ }^{53}$ but a chapel in front of the castle is mentioned in $1555 .{ }^{54}$

52 "Protocoll der Catholischen Kirchenvisitation in Livland von Jahre 1613", Archiv für die Geschichte Liv-, Esth-und Curlands, Bd. I, ed. by Friedrich Georg von Bunge (Reval, 1857), 43-44; Liivimaa 1638. a. maarevisjon: Eesti asustusala I: kaguosa. ENSV Riigi Keskarhiiv Tartu osakonna Toimetused, 1 (7) (Tartu: Teaduslik Kirjandus, 1941), 97.

53 Kaur Alttoa, "Karksi keskajal. Mõningaid probleeme", Viljandi Muuseumi Aastaraamat 2008 (Viljandi: Viljandi Muuseum, 2009), 270

54 Juhan Kreem, "Märkmeid Karksi linnuse piirkonnast ja selle kirikuelust", Järelvastamine Kaur Alttoale, ed. by Anneli Randla. Eesti Kunstiakadeemia toimetised, 22. Muinsuskaitse j konserveerimise osakonna väljaanded, 7 (Tallinn: Eesti Kunstiakadeemia, 2017), 33-50.

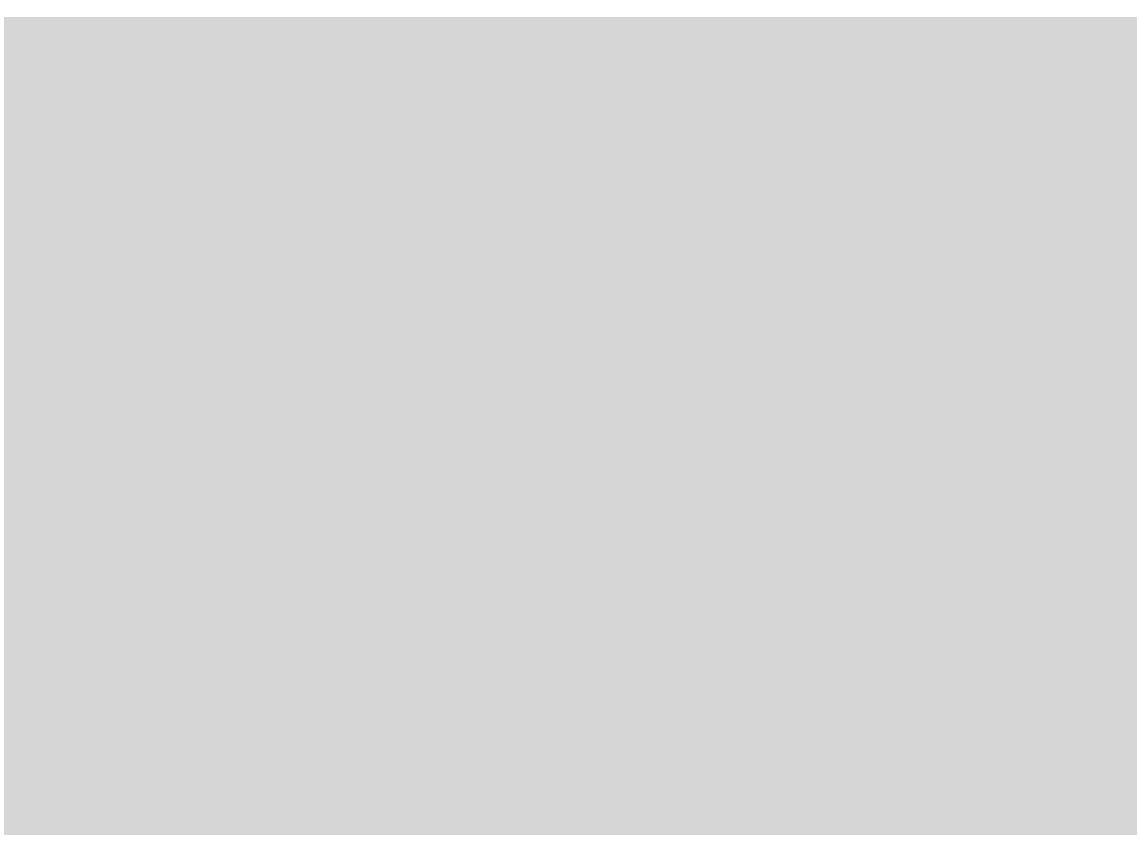

Fig. 8. Finds from Palamuse (1), Maarja-Magdaleena (2), Nõo (3) and Urvaste (4-7) churchyards. $1-3$ brooches; 4 - cowry shells; 5 - pendant; 6 - ring; 7 - knife (TaM A 111 2; TÜ 2583: 2; TÜ 2520: 18; TÜ 708: 6, 3, 1, 8). Photo: Heiki Valk.

As the land census of 1624 notes that this was a church, ${ }^{55}$ it was a major building. Human bones have been found in the present-day car park at its location.

Tartu bishopric: northern Tartumaa. From the churchyards of northern part of historical Tartumaa district, the only evidence of prehistoric graves is from Maarja-Magdaleena, which was first mentioned as new auxiliary church of Palamuse Church in 1380; by 1443 an independent parish existed. ${ }^{56}$ Finds from the churchyard (ÕES 1905: 1-4; AI 2712: 122; AI 4882; AI 4883; ERM 18560; ERM A 167: 62 ; TÜ 2583) include several $13^{\text {th }}-15^{\text {th }}$ century items, including a small Gothic brooch (Fig. 8: 2). Some of these finds may pre-date the churchyard, originating from an earlier village cemetery of the

55 Oleg Roslavlev, Das Pernauer Land 1624, ed. by Oleg Roslavlev. Hefte zur Landeskunde Estlands, 2 (München, 1967), 69.

56 Axel von Gernet, Verfassungsgeschichte des Bisthums Dorpat bis zur Ausbildung de Landstände (Dorpat: Schnakenburg, 1896), 17-18; Arbusow, Livlands Geistlichkeit vom End des 12. bis ins 16. Jahrhundert, 315 . 
Christian period. Numerous cremated bones (TÜ 2583) suggest the Iron Age origin of the cemetery.

Several finds originate from the churchyard of Palamuse where a priest was mentioned in $1234 .{ }^{57}$ The choir of the church may date from the $13^{\text {th }}$ century. ${ }^{58}$ Numerous stray finds include a $13^{\text {th }}$ century penannular brooch (Fig. 8: 1), three tiny $13^{\text {th }}-15^{\text {th }}$ century bronze bells (TaM A 114: 1-3) and a fragment of $13^{\text {th }}-14^{\text {th }}$ century penannular brooch (TaM A 119: 2).

The parish of Äksi, first mentioned in $1443,{ }^{59}$ was probably founded during the Crusades. This is indirectly indicated by its location in the core of the densely populated Jogentagana province north of the Emajõgi River. ${ }^{60}$ Judging by a drawing from before the reconstruction of 1887-1889, the medieval stone church may date from the same period as the Põlva church, ${ }^{61}$ i.e., from the end of the $15^{\text {th }}$ century. ${ }^{62}$ Among the preserved finds, mostly of later origin, only a tiny bronze bell (ÕES 1701: 3) and data about cowry shells (AI, Mss 113 (17)) refer to $13^{\text {th }}-15^{\text {th }}$ century graves.

The church in Kursi is first mentioned as a ruined stone building in 1624/27. ${ }^{63}$ It may possibly be identical to the parish church of Lemstefer, as the name Kursi is derived from the name of a landowner of the manor. ${ }^{64}$ The ruined church was rebuilt in 1648, and was reconstructed in $1871-1872^{65}$ so completely that no architectural data on the medieval building can be provided. The earliest archaeological evidence is a fragment of a medieval bracteate penny of Tartu bishopric from the $13^{\text {th }}-14^{\text {th }}$ centuries (TÜ 2503: 8). ${ }^{66}$

57 Hildebrand, Livonica, vornämlich aus dem 13. Jahrhundert im vatikanischen Archiv, 49. 58 Alttoa, "Märkmeid Lõuna-Eesti keskaegsetest maakirikutest", 68.

59 Livländische Güterurkunden (aus den Jahren 1207 bis 1500), Bd. I, ed. by Hermann von Bruiningk, Nicolaus Busch (Riga: Jonck \& Poliewsky, 1908), no. 311.

60 Andres Tvauri, Muinas-Tartu: uurimus Tartu muinaslinnuse ja asula asustusloost. Muinasaja teadus, 10 (Tartu, Tallinn: Teaduste Akadeemia Kirjastus, 2001), 203-208, Fig. 97.

61 Voldemar Vaga, Памятники архитектуры Эстонии (Ленинград: Стройиздат, Ленинградское отделение, 1980), 91.

62 Alttoa, "Märkmeid Lõuna-Eesti keskaegsetest maakirikutest", 80

63 Oleg Roslavlev, Das Dorpater Land 1624/27, Hefte zur Landeskunde Estlands, 1 (München, 1965), 13.

64 Die evangelisch-lutherischen Gemeinden in Russland, 262.

65 Ibidem.

66 Determined by Mauri Kiudsoo (University of Tallinn).

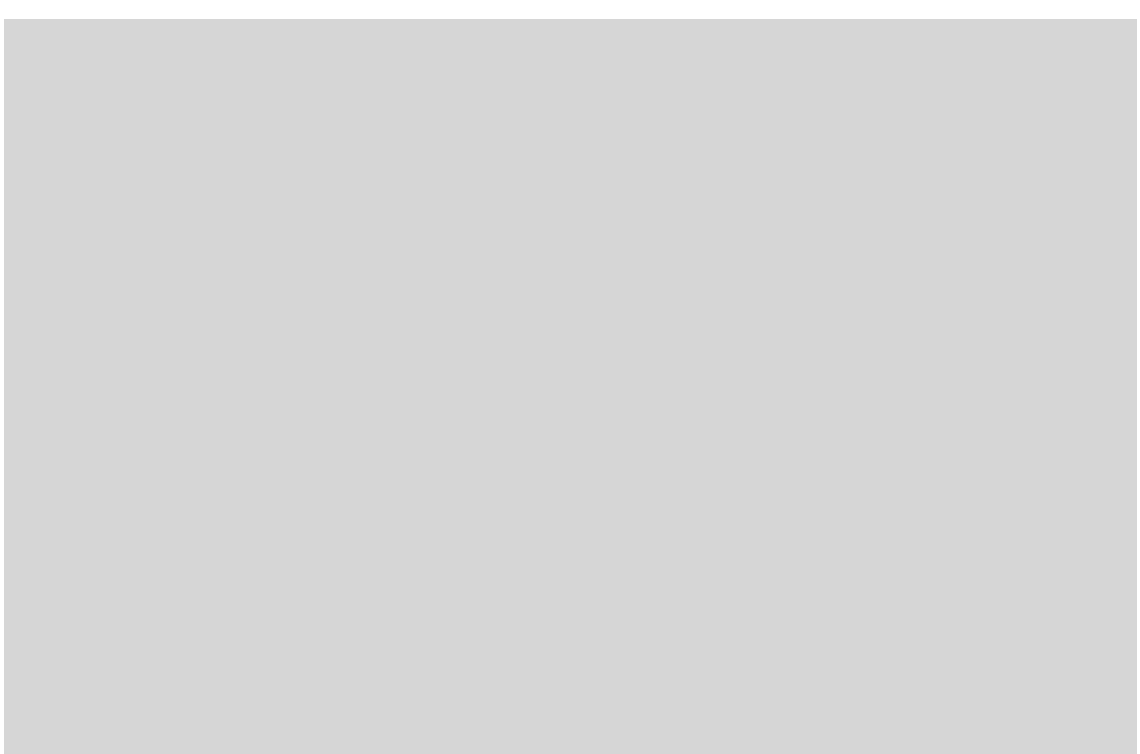

Fig. 9. The church in Rõngu, built on a Final Iron Age cemetery and re-constructed in 1901. Photo: Heiki Valk.

In Kodavere the parish was first mentioned in $1443,{ }^{67}$ but the site of the medieval church is unknown. The church has been in the new location since 1671, the present stone building was completed in $1777 .^{68}$ Brooches, rings, coins and necklaces found when digging a cellar in the 'old cemetery' at the parsonage - from which only a shieldshaped $13^{\text {th }}-14^{\text {th }}$ century ring (AI 1647) has survived - may refer to the medieval parish cemetery. However, in the spring of 2017, a medieval cemetery with numerous finds (TÜ 2666), the earliest from the first half of the $13^{\text {th }}$ century, was found ca. $150 \mathrm{~m}$ east of the parsonage, beside the new road. This site may also have functioned as the first parish cemetery. No finds from the churchyard in Laiuse exist and the location of medieval Torma Church is unknown.

Tartu bishopric: southern Tartumaa. The largest assemblage of finds from the southern part of Tartumaa originates from churchyard in Rõngu (Fig. 9), which borders on a Final Iron Age and medieval settlement site. The parish church was first mentioned in 1413 as a

67 Livländische Güterurkunden, Bd. I, no. 311

68 Die evangelisch-lutherischen Gemeinden in Russland, 258. 


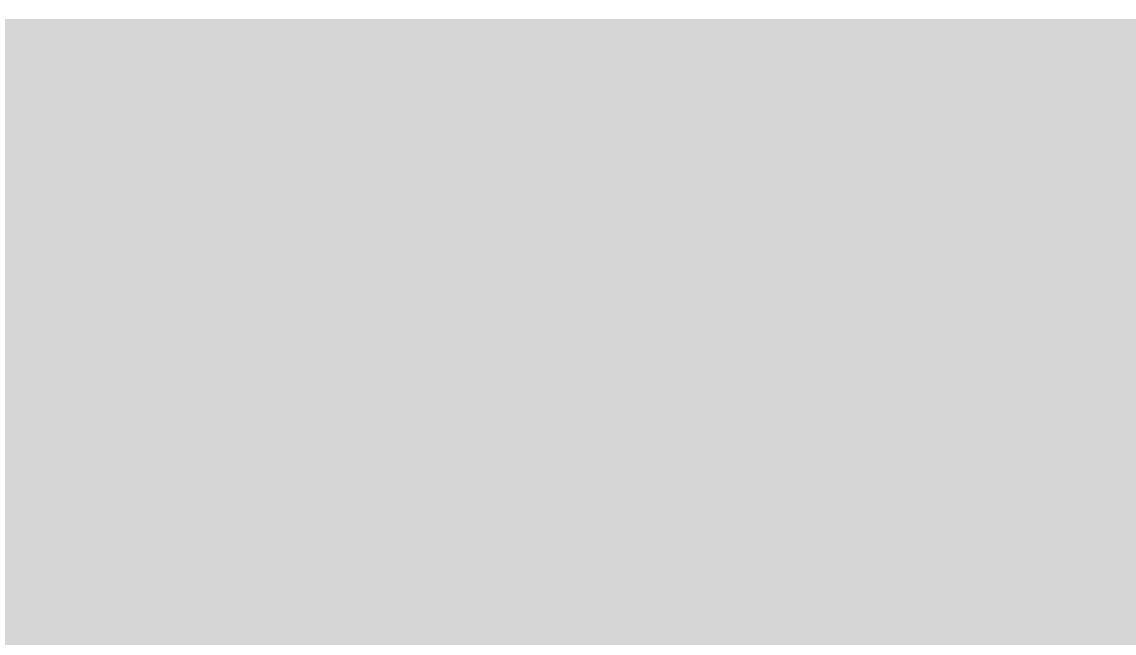

Fig. 10. Finds from Rõngu churchyard. 1, 2, 4, 5 - bracelets; 3 - brooch; 6 - ring; 7 - breas chain (TÜ 2256: 4, 3, 6, 1, 2, 26, 39). Photo: Heiki Valk.

site where visitors and supporters could receive absolution, ${ }^{69}$ but the medieval building was so profoundly re-constructed in 1901 that its age cannot be determined. The artefact finds without fire traces (AI 2256: 1-62; TÜ 703: 1-9) indicate a pre-Christian cemetery, mostly with inhumations, but some cremated bone fragments were also found (TÜ 703: 25, 26). Beside a spearhead (ÕES 2256: 41), the earliest Iron Age finds include four Final Iron Age bracelets (Fig. 10: 1, 2, 4, 5), a fragment of a breast chain (Fig. 10: 7) and a penannular brooch with joined flat ends (Fig. 10: 3). The brooch is a derivate form of the $11^{\text {th }}$ century Gotlandic animal-headed brooches; similar derivates also occur in Latvia, especially in the graves of the Daugava Livs in the $11^{\text {th }}$ century. ${ }^{70}$ The find from Rõngu is the only such brooch in Estonia. Several finds from the $13^{\text {th }}$ and $14^{\text {th }}$ century - flat thin bracelets, a medieval ring brooch, a massive penannular brooch - suggest the cemetery was in continuous use until becoming a churchyard. As the area of the Rõngu parish was probably not a separate administrative

69 Arbusow, Livlands Geistlichkeit vom Ende des 12. bis ins 16. Jahrhundert, 316.

70 Guntis Zemītis, "Pakavsaktas ar stilizētiem ažūriem zvêrgalvu galiem Latvijā", Arheoloǵija un etnogräfija, XXIII (Rịga: Latvijas Vēstures Institūta Apgāds, 2006), 338-345; Anna Zariña, Salaspils Laukskolas kapulauks. 10.-13. gadsimts (Rīga: Latvijas Vēstures Institūta apgāds, 2006), 284, Figs. 139: 40, 179: 2

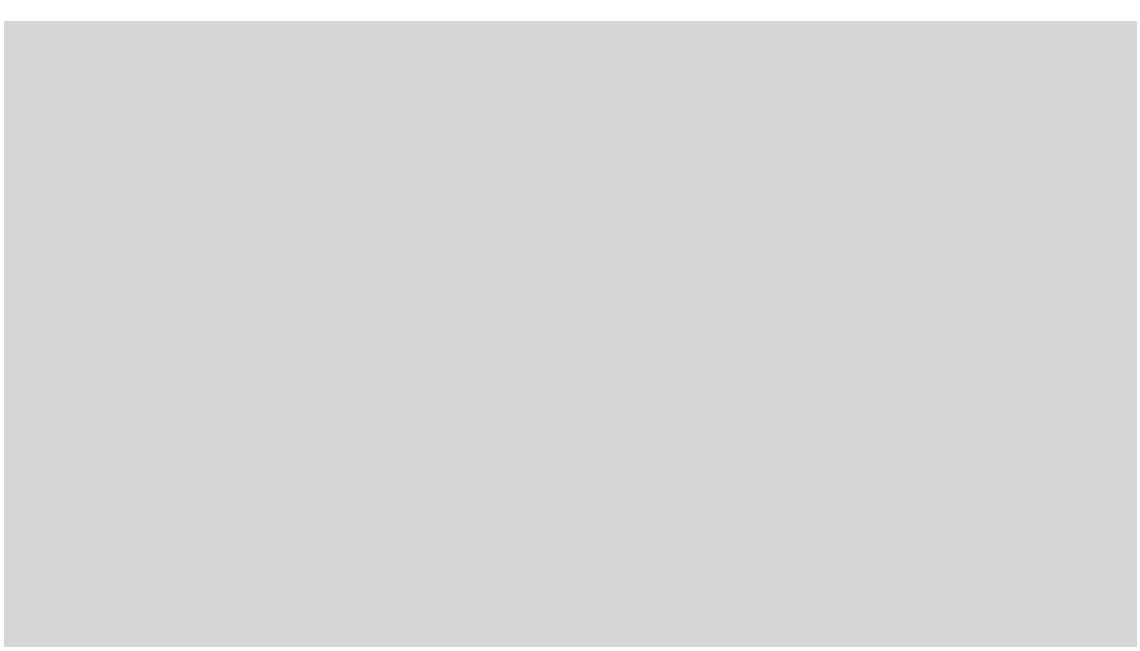

Fig. 11. Finds from Kambja $(1,3)$ and Võnnu (2) churchyards. 1, 2 - bracelets with traces of fire; 3 - biser bead (TÜ 709: 31; TM A 167; TÜ 709: 17). Photo: Heiki Valk.

unit in the Final Iron Age, ${ }^{71}$ the cemetery seems to have functioned as a local village cemetery, maybe with a Catholic chapel, until the making of the parish and parish church. In 1998 the rampart around the churchyard was broken by a broad trench. The finds discovered in the ground, although including human bones, a cowry shell and some bronze spiral tubes from disturbed graves, confirm its late origin - maybe not until the reconstruction of 1901.

The finds from Kambja also demonstrate that the cemetery has a longer history than the parish church. The first mention of a priest in Kambja dates back to $1330^{72}$ and the parish to $1471 .{ }^{73}$ According to the scanty medieval architectural data, the stone church may date from the late $15^{\text {th }}$ or early $16^{\text {th }}$ century. ${ }^{74}$ Although finds from the earlier earthwork and excavations (ÕES 1091: 1-7; TÜ 501: 1-108) indicated the churchyard's medieval and post-medieval date, the finds from 1998 (TÜ 709: 1-33) from the area around the choir, including a burnt bracelet from the late $11^{\text {th }}$ or $12^{\text {th }}$ century (Fig. 11: 1) and some cremated

71 Tarvel, "Sakala ja Ugandi kihelkonnad", 592.

72 Arbusow, Livlands Geistlichkeit vom Ende des 12. bis ins 16. Jahrhundert, 314.

73 Livländische Güterurkunden, Bd. I, no. 476.

74 Alttoa, "Keskaegsest Kambja kirikust", 79. 
bones, prove the Iron Age origins of the cemetery. Several $13^{\text {th }}-14^{\text {th }}$ century finds in the assemblage - a round brooch with Gothic plant ornamentation (TÜ 709: 6), a penannular brooch with knob-shaped ends (TÜ 709: 30), fragments of flat bracelets (TÜ 709: 10, 26), bronze spiral tubes (TÜ 709: 3, 5, 8, 32), and a tiny biser bead (Fig. 11: 3) suggest the cemetery was in continuous use since the Iron Age.

In Võnnu the oldest part of the repeatedly reconstructed church may date back to the $13^{\text {th }}$ century; ${ }^{75}$ first written data about the parish are from $1360 .{ }^{76}$ Two bracelets - a grooved item, slightly broken (in fire?) (Fig. 11: 2), and fragment of a six-facetted bracelet (ViM 75), a type that occurs mainly between 1050 and $1100 \mathrm{AD}^{77}$ - prove that the cemetery in the churchyard dates back to the Final Iron Age. The first of the bracelets was found in the 1960s from a gravel pit southeast of the church.

In Nõo where the stone church was built in the middle or third quarter of the $13^{\text {th }}$ century, ${ }^{78}$ and where a priest was first mentioned in $1315,{ }^{79}$ the oldest medieval finds are a tiny penannular brooch, probably from the $13^{\text {th }}$ century (Fig. $8: 3$ ), a $13^{\text {th }}-14^{\text {th }}$ century ring brooch (AI 2500: 3) and some bronze spiral tubes (TÜ 2520: 21). A Late Iron Age cremation cemetery is attested to by the fragments of cremated bones and pieces of hand-made pottery (TÜ 694: 2; TÜ 2520: 16, 23).

In Rannu where a priest was first mentioned in $1347^{80}$ and the stone church probably dates from the $2^{\text {nd }}$ quarter of the $15^{\text {th }}$ century ${ }^{81}$ the few finds from the churchyard (ERM A 565: 11-13) include a spiral ring that pre-dates the mid- $15^{\text {th }}$ century. From the churchyards in Otepää and Sangaste, where the architectural evidence is insufficient to even speak about the medieval origin of the church, there are no artefact finds. In Otepää - there a parish was evidently founded

75 Alttoa, "Märkmeid Lõuna-Eesti keskaegsetest maakirikutest", 69.

76 Arbusow, Livlands Geistlichkeit vom Ende des 12. bis ins 16. Jahrhundert, 317.

77 Marika Mägi-Lõugas, "Eesti viikingiaegsed käevõrud ja nende ornament”, Eesti arheoloogia historiograafilisi, teoreetilisi ja kultuuriajaloolisi aspekte (Tallinn: Teaduste Akadeemia Kirjastus, 1995), 305.

78 Alttoa, "Nõo Laurentsiuse kirikust".

79 Arbusow, Livlands Geistlichkeit vom Ende des 12. bis ins 16. Jahrhundert, 310, 315.

80 Ibidem, 316

81 Alttoa, "Märkmeid Lõuna-Eesti keskaegsetest maakirikutest", 73-75. in 1215 , and the place became bishop's residence in $1223^{82}$ - a hint about the continuity of church site is provided by the information on bone finds from the churchyard. A note about weapons found when reconstructing the church in the $19^{\text {th }}$ century (AI, Mss 160 (3)), if not a folkloric exaggeration, may refer to a Late Iron cemetery. No data about finds exists from the cemetery at Puhja Church, including from the archaeological monitoring conducted inside the church in 2004.

Medieval artefacts from the urban cemeteries of St John's Church and St Mary's Church in Tartu are not numerous and the finds are mostly of post-medieval origin. ${ }^{83}$ However, in some of the earliest female graves at St Mary's cemetery, there are finds of Estonian jewellery and bronze spiral tubes from the $13^{\text {th }}$ century ${ }^{84}$ and the situation is similar at St John's cemetery. In both cases, there are no signs of an Iron Age burial ground, although the dendrochronological date of a tree-trunk coffin from St John's churchyard confirms that the tree was cut in $1223 .{ }^{85}$ Evidently, the cemetery was founded very soon after the conquest of Tartu in 1224. The lack of medieval jewellery is also characteristic of the Tartu Cathedral cemetery and interior. Unlike the town cemeteries noted above, there are no data about $13^{\text {th }}$ century Estonian female burials. The earliest jewellery item, which may be from the graves, is a penannular brooch from the first half or middle of the $13^{\text {th }}$ century. ${ }^{86}$ All three cemeteries were preceded by settlement sites, evinced by intensive occupation layers - mainly from the $11^{\text {th }}$ century. Judging by the finds from the excavations of 2014 (TM 222), St Jacob's cemetery was founded outside the medieval town walls of Tartu in the $2^{\text {nd }}$ half of the $13^{\text {th }}$ or in the $14^{\text {th }}$ century. However, some disturbed fragments of cremated human bones, indicating its possible Late Iron Age origin, were also found in the cemetery.

82 Henriku Liivimaa kroonika, XXVIII: 1.

83 Heiki Valk, "Grave goods in Estonian Urban Churchyards: A Reflection of different Traditions and Ideologies", Der Ostseeraum und Kontinentaleuropa 1100-1600. Einflussnahme-Rezeption-Wandel Helms, 2004), 106, Tab. 3, 5 .

84 Malve, Roog, Tvauri, “Preliminary results of the Rescue Excavations in St Mary's Churchyard and its Surroundings in Tartu 2010-2011", 140-144.

85 Alar Läänelaid, "Jaani kiriku algus ja aastarõngad", Horisont, 1 (2002), 34.

86 Valk, "Tartu Toomkiriku kalmistust", Fig. 9. 


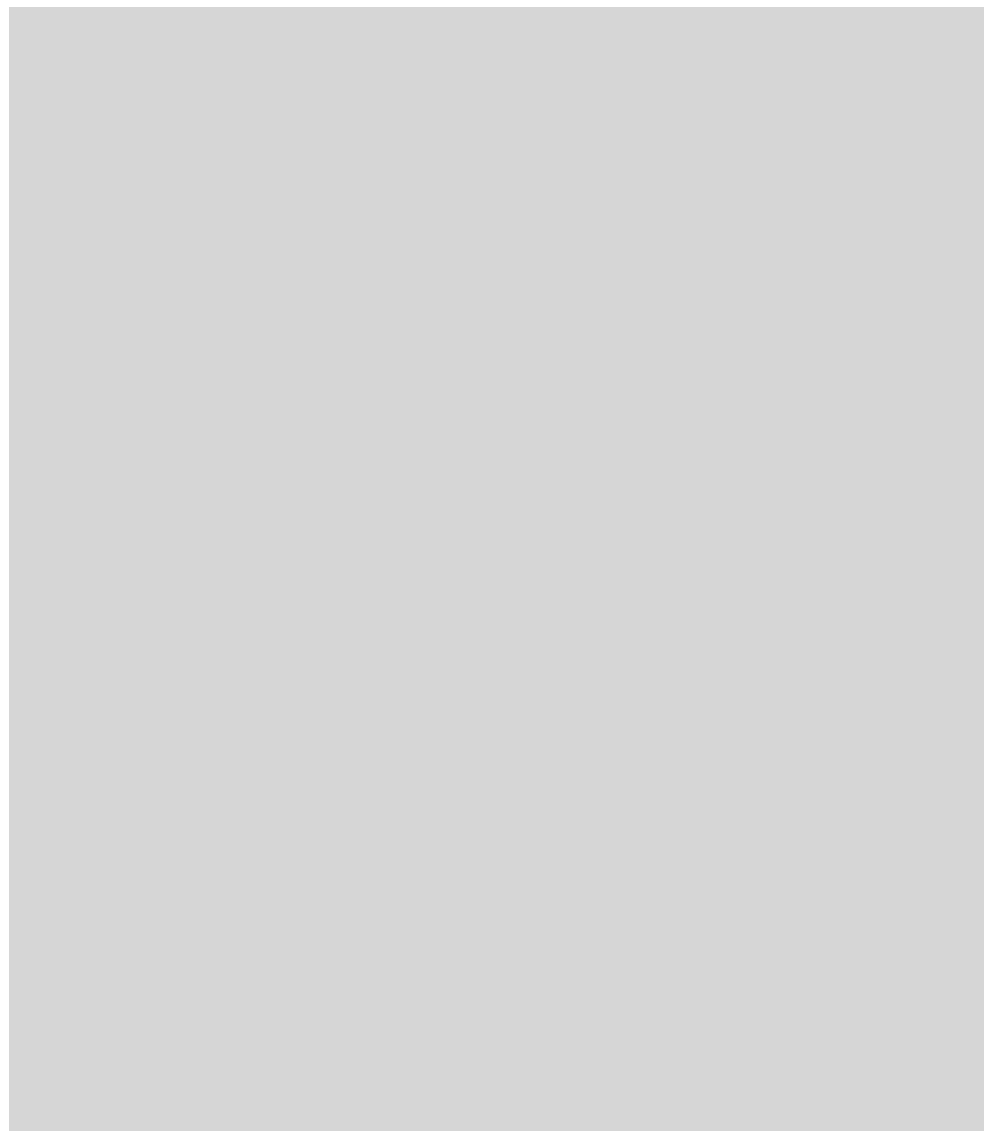

Fig. 12. The church in Urvaste, $14^{\text {th }}$ century, with churchyard finds since the $13^{\text {th }}$ century. Photo: Heiki Valk.

Tartu bishopric: Võrumaa. Judging by its architecture, the Urvaste church (Fig. 12) in historical Võrumaa, first mentioned in connection with the pilgrims' absolution in $1413,{ }^{87}$ dates no further back the $14^{\text {th }}$ century, and it did not become a basilica before the last quarter of the century. ${ }^{88}$ Finds from the test pits dug in the west of the nave in 1987 (TÜ 708: 1-9) include some $13^{\text {th }}-$ mid- $15^{\text {th }}$ century items (Fig. 8: $4-7)$, but also a bracteate minted in Visby 1225-1288 AD. Another

87 Arbusow, Livlands Geistlichkeit vom Ende des 12. bis ins 16. Jahrhundert, 312

88 Alttoa, "Die Kirche zu Urbs/Urvaste und die Frage der Rigenser Bauschule im 13. Jahrhundert", necklace of cowry shells (VaM A 5: 1) belongs to the same period and there is also information about undocumented finds of knives (incl. with antler handle), rings, bracteates and cowry shells. ${ }^{89}$

In Põlva, where the parish was first mentioned in $1452,{ }^{90}$ and the church tower dates from the late $15^{\text {th }}$ century, ${ }^{91}$ the fact that the cemetery was used in medieval times is shown by a flat round brooch. ${ }^{92}$ In Rõuge the location of the medieval stone church, which was built, according to local lore documented in 1638, at the time of bishop Johannes, evidently, Johannes V Bey (1528-1543), ${ }^{93}$ is unknown. The old church was demolished in 1729 and the new one finished in 1730. The only find from the churchyard is a heart-shaped brooch from Early Modern Times (ERM A 323: 26). From Karula, where the parish is first mentioned presumably in $1392,{ }^{94}$ and definitely in $1532{ }^{95}$ the stone church may date back to the end of the $15^{\text {th }}$ century ${ }^{96}$ but there are no artefact finds. The exact location of medieval parish church of Kirumpää, mentioned in $1432,{ }^{97}$ is unknown.

The four other rural parishes of Võrumaa - Vastseliina, Kanepi, Räpina and Hargla - were not founded until the $17^{\text {th }}$ century. However, in Kanepi, where a pastor is first mentioned in $1671^{98}$ and the first timber church was built in $1674,{ }^{99}$ there are data about finding burnt bones, stones and charcoal, referring to an Iron Age stone grave, as well as about strongly decayed bones and a late medieval coin referring to a medieval village burial ground. The

89 Oral data from pastor Villu Jürjo to the author in 1998

90 Livländische Güterurkunden. Bd. I, no. 354

91 Alttoa, "Märkmeid Lõuna-Eesti keskaegsetest maakirikutest", 79.

92 Hermann Eduard Hartmann, Das Vaterländische Museum zu Dorpat oder die Sammlungen der gelehrten estnischen Gesellsachaft und des Central-Museum vaterländischer Alterthümer der Kaiserlichen Universität zu Dorpat. Verhandlungen der Gelehrten Estnischen Gesellschaft, VI, Heft 3/4 (Dorpat: H. Laakmann, 1871), 155, Pl. XV: 36d.

93 Liivimaa 1638. a maarevisjon. Eesti asustusala I. Kaguosa, 167.

94 Arbusow, Livlands Geistlichkeit vom Ende des 12. bis ins 16. Jahrhundert, 315. The parish name Carwele can also be read as Taiwele.

95 Gernet, Verfassungsgeschichte des Bisthums Dorpat bis zur Ausbildung der Landstände, 73.

96 Alttoa, Lõuna-Eesti arhitektuur 15. saj--16. saj. I poolel, 134.

97 Arbusow, Livlands Geistlichkeit vom Ende des 12. bis ins 16. Jahrhundert, 315

98 Die evangelisch-lutherischen Gemeinden in Russland, 208.

99 Võrumaa. Maadeteaduslik, tulunduslikja ajalooline kirjeldus, ed. by Jaan Rumma, Augus Tammekann, Johannes Voldemar Veski (Tartu: Eesti Kirjanduse Selts, 1926), 179. 
finds were unearthed between the churchyard and the present-day parish cemetery. ${ }^{100}$ In Valga where a priest existed in $1286,{ }^{101}$ the St John's Church was built in 1787-1816 102 on site of an earlier cemetery, as shown by the finds of $13^{\text {th }}-14^{\text {th }}$ century brooches (VaM A 19: 35,65 ). In Vastseliina a priest, probably of the auxiliary church of Rõuge, was first mentioned in 1525; ${ }^{103}$ the first Lutheran pastor was active between 1626 and $16333^{104}$ and a new wooden church was noted in $1638 . .^{105}$ The oldest known cemetery with graves from the $16^{\text {th }}$ and $17^{\text {th }}$ century ${ }^{106}$ was situated in front of the castle, on the bank of the Miikse creek. After the war of 1656-1661, the church and the parish cemetery were moved to another location. No medieval graves are known from the churchyards in Hargla and Räpina.

Archaeological data sometimes demonstrates that the old churchyard was bigger than the present one. In Nõo in 2015, bones were found west, north and east of the churchyard wall, ${ }^{107}$ which was probably built soon after $1820,{ }^{108}$ and oral lore and finds indicate that the churchyard previously extended farther south. ${ }^{109}$ As noted above, the churchyard in Võnnu extended into the Soviet-era gravel quarry southeast of the church; in Maarja-Magdaleena - up to $80 \mathrm{~m}$ south of the church. ${ }^{110}$ In Põltsamaa the churchyard's previous eastern boundary, designated by a NW-SE directional stone wall and its south-western corner with skeletons under it have been discovered. ${ }^{11}$

100 Vaba Maa, no. 162, 17.07.1929.

101 Arbusow, Livlands Geistlichkeit vom Ende des 12. bis ins 16. Jahrhundert, 317.

102 Die evangelisch-lutherischen Gemeinden in Russland, 167.

103 Arbusow, Livlands Geistlichkeit vom Ende des 12. bis ins 16. Jahrhundert, 313.

104 Oleg Roslavlev, Kirchspiel Neuhausen, Siedlungsgeschichte des Estenlandes, 3 (München, $1976), 6$.

105 Liivimaa 1638. a. maarevisjon: Eesti asustusala I: kaguosa, 160-161.

106 Unpublished data from the excavations of 2017. Finds: TÜ 2645.

107 Martin Malve, Päästekaevamised Nõo Püha Laurentsiuse kirikaias 2015. a. (Tartu, 2017). Manuscript in the archaeological archives of the University of Tartu.

108 Plank, "Nõo kihelkonna ajalugu", 2.

109 TaM Aj 58:1-5; AI, Mss 115i.

110 Erik Tootsi, Jogentagana asustuslugu kuni 17. sajandi lõpuni. Diploma thesis (Tartu: Tartu Ülikool, 1999), 45. Manuscript in the archaeological library of the University of Tartu.

111 Peeter Piirits, Arheoloogilised järelvalvetööd Pôltsamaal Veski ja Lepa tn trasside rajamisel (Tartu, 2013). Manuscript in the archaeological archives of the University of Tartu.

\section{DISCUSSION: THE ORIGINS OF CEMETERIES IN MEDIEVAL CHURCHYARDS}

As shown above, archaeology has opened a new aspect in the history of churchyards in southern Estonia: the cemeteries may pre-date the churches or parishes, and often have their roots in pre-Christian time. The finds of Final Iron Age artefacts from Rõngu, Võnnu, KolgaJaani and Kambja, in the first two or three cases from cremation graves, as well as, most likely, the jewellery from Pilistvere, indicate the presence of a cemetery on the site of the future church already before the Christianization. The same message is provided by the cremated human bones from Pilistvere, Halliste, Kolga-Jaani, Paistu, Maarja-Magdaleena, Rõngu, Kambja and Nõo churchyards, ${ }^{112}$ as well as by the hand-moulded pottery fragments from Nõo and Pilistvere. Although in some cases it cannot be excluded that the cremains originate from exhumed bones that happened to be burnt in a bonfire in the churchyard, e.g. during some reconstruction work, such cases cannot be an explanation for the situation in general.

Thus, in southern Estonia, there are a considerable number of medieval parish churches with finds that attest to an Iron Age cemetery. Without including the churches with insufficient archaeological source material (having no finds or finds represented with single or rare items collected in the $19^{\text {th }}$ century, when the probability of picking up dispersed burnt bone fragments was minimal), as well as the churchyards of medieval Tartu and Viljandi (there the construction of the churches is apparently related to the town genesis), the number of potential sites with Iron Age grave finds is reduced from 35 to 15 . Among the latter, a total of nine sites, i.e. $60 \%$ (!) have archaeological evidence indicating Late Iron Age cremation burials (Fig. 1). In addition, cremated bone fragments were also found in the St Jacob's suburban cemetery in Tartu. Although data are fragmentary and based on stray finds, they show a clear correlation between churches and pre-Christian cremation cemeteries. Moreover, in the rest of the cases as well, the amount of archaeological data is often so limited that future finds indicating cremation graves are possible. Only in Tarvastu can the

112 The presence of definitely human bones in all these cemeteries was confirmed by Anu Kivirüüt (National Heritage Board) who has specialized in the study of cremains and who reviewed the bone fragments. 
existing number of finds be regarded as representative enough to assume that the church was probably not preceded by a preChristian cremation cemetery. Nevertheless, even there, Final Iron Age graves cannot be excluded.

Theoretically, we can consider the possibility that some of the cremains from the churchyards may not be prehistoric but date back to medieval times: cremations continued sporadically and to a limited extent in southern Estonia during medieval times as well, ${ }^{113}$ and rare $13^{\text {th }}$ century cremation graves also have been found in Livonia's earliest, largely excavated Liv churchyards in Ikškile and Mārtin,sala. ${ }^{114}$ However, as in the Liv churchyards, the number of medieval cremations, considering the total number of investigated burials, is very low - only two in Ikškile and one in Mārtin,sala (from a total of 1,753 excavated graves) - their numerous presence in the churchyards of southern Estonia seems most unlikely.

The continuity from pre-Christian cremation cemeteries to churchyards demonstrates that the local communities were actively involved in determining the places where the parish churches would be built. The churches constructed on Late Iron Age cemeteries show that building a Christian sanctuary on the graves of their ancestors and relatives was considered accepted for the inhabitants of southern Estonia - in spite of the very violent nature of the Christianization of the region. Such a practise can also be regarded as a sign of a post-conquest positive or respective attitude towards Christianity, ${ }_{1}^{115}$ or at least, towards its promising aspects concerning afterlife. On the other hand, the reason for place continuity may also have been the natives' wish to be buried together with the deceased members of their families and kin. Evidently, this basic principle was also the main reason for the long-term use of local village cemeteries in Estonia and Latvia. In both cases, burials outside churchyards

113 Heiki Valk, "Põletusmatustest keskaegses Lõuna-Eestis", Kleio. Ajaloo ajakiri, 7 (Tartu 1993), 5-13; Valk, Rural Cemeteries of Southern Estonia 1225-1800 AD, 64-66; Valk, Laul, Siksälä kalme, 74-76; Vitolds Muižnieks, Bēru tradīcijas Latvijā pēc arheologiski pêtìto 14.-18. gadsimta apbedīšanas vietu materiāla. Latvijas Nacionālā Vēstures Muzeja Raksti, 21 (Riga: Latvijas Nacionālais Vestrires Muzejs, 2015), 62.

114 Vitolds Muižnieks, "Apbedīšanas tradīcijas Mārtinnsalas baznīcas kapsētâ", Arheoloğija un etnogrāfija, XXIII (Rīga: Latvijas Vēstures Institūta Apgāds, 2006), 167.

115 In 1211 the Saccalians, when subordinated to the crusaders, declared the God of Christians to be stronger than the old gods: by achieving the victory in war He had forced them to respect Him (Henriku Liivimaa kroonika, XIV: 14). continued until the early $18^{\text {th }}$ century. ${ }^{116}$ In any case, the archaeological record does not speak of any opposition to having the sanctuary of the new religion built on the pre-Christian cemetery. Archaeological record referring to a similar situation exists also from northern and western Estonia, e. g. the churchyards of Valjala in Saaremaa, Pühajõe in Virumaa, Saha in Harjumaa, Türi in Järvamaa, etc.

One explanation for place continuity may be the papal letters to Bishop Albert and the Order of Sword Brethren from 1214 or 1215 , which confirm that the neophytes of Livonia should be buried 'according to their will' (eligant sepulturam ad eorum voluntatem). ${ }^{117}$ Evidently, this practice was introduced to avoid conflicts with the neophytes in a situation where their support was very necessary for the authorities of medieval Livonia.

In the framework of these concessions, we should also consider the case of the Liv Christian Prince Caupo who was killed in battle in 1217 and cremated, and whose bones were taken to his home place and buried there ${ }^{118}$ - evidently, in the churchyard -, as well as the rare cremations from Ikškile and Mārtinsala churchyards. However, as proved by archaeological evidence from the largely excavated cemeteries of Ikškile and Mārtinsala, such cases are exceptional, and not relevant for explaining the numerous cases of cremation from the churchyards of southern Estonia.

When a church was founded on an Iron Age cremation cemetery, the first question that emerges is the temporal continuity of burial tradition. Most likely, in cases where there are data referring to a church in the first half of the $13^{\text {th }}$ century, there is no reason to suggest a break. Such continuity is also demonstrated by the Final Iron Age artefacts from the Pilistvere and Võnnu churchyards. The time gap between the pre-Christian cemetery and church construction is considerably short in Nõo as well.

Also in cases where no written or architectural data referring to a church exists from the first half or the $13^{\text {th }}$ century, the Iron Age cemetery with cremation graves has most likely been in continuous

116 Valk, Rural Cemeteries of Southern Estonia 1225-1800 AD; Muižnieks, Bēru tradīcijas Latvijä pēc arheologíski pētìto 14.-18. gadsimta apbedīšanas vietu materiāla.

117 Leonid Arbusow, Römischer Arbeitsbericht, I: mit einem Anhang von Papstregesten des 13. und 14. Jahrhunderts und von Urkunden. Acta Universitatis Latviensis, XVII (Riga: Latvija Universitāte, 1928), 296-297, 323.

118 Henriku Liivimaa kroonika, XXI: 4 
use until becoming a churchyard - as a medieval village cemetery with inhumation burials: at the time when burial in the villages was a common and continuous practise, there is no reason for discontinuity. Thus, in Rõngu where the parish centre was founded, probably after the crusades and Christianization, and the presence of a separate administrative unit (kihelkond) seems unlikely in the Final Iron Age, $13^{\text {th }}-14^{\text {th }}$ century grave finds refer to the continuous use of Iron Age cemetery. The status of Kambja in the early $13^{\text {th }}$ century is unclear, but also here there is no sufficient argumentation to suggest a Late Iron Age kihelkond centre.

The status of an early medieval burial ground - was it a village cemetery or a churchyard? - is also a question in Urvaste and Äksi. The earliest grave finds from these churchyards date back to the $13^{\text {th }}-14^{\text {th }}$ centuries, but there are no written or architectural data about churches existing before the $14^{\text {th }}$ century. In these cases, the grave finds may come from the churchyard of a timber church, or a village cemetery of medieval origin, which was perhaps furnished with a chapel. Nevertheless, at least in Äksi, there is reason to suggest the presence of a Final Iron Age regional centre. And therefore, it is possible to interpret the early grave finds as coming from a parish churchyard that is not recorded in other sources.

Among the churchyards with archaeological finds, the lack of a connection between a pre-Christian cremation cemetery and a churchyard currently seems probable only in Urvaste and Tarvastu; although in Tarvastu, as noted above, a Final Iron Age inhumation cemetery cannot be excluded. In Urvaste the probability of a preChristian inhumation cemetery is small, since there are $13^{\text {th }}$ century grave finds, probably from the first half of that century, from a valley ca. $600 \mathrm{~m}$ southwest of the church, in the vicinity of the former Alakõrtsi inn. ${ }^{119}$ As Urvaste Church is on the border between the Antsla (German, Anzen) and Vaabina (German, Uelzen) Manors, which probably belonged to the Üksküll and Tiesenhausen families in medieval times, ${ }^{120}$ its location seems to have been determined soon after the conquest not by the locals, but by the vassal families, who were patrons of the church. The place for the church was probably

119 VaM A 5: 2-5. A late $12^{\text {th }}$ or early $13^{\text {th }}$ century female grave was discovered and excavated there by the National Heritage Board also in July 2017.

120 Alttoa, "Die Kirche zu Urbs/Urvaste und die Frage der Rigenser Bauschule im 13 Jahrhundert", $42-43$. chosen because of its more prominent location in the landscape. A Visby coin dated between 1225 and 1288 suggests that the stone church had a wooden predecessor. It seems likely that when the church was founded in its present location, the earlier cemetery at Alakõrtsi inn was deserted and burial site was transferred to the new churchyard.

However, in some cases, there seems to have been a longer time gap between the pre-Christian cemetery and the churchyard. And this may have been the case in Maarja-Magdaleena where a new auxiliary church was noted in 1380, but in spite of the cremains, no definite grave finds from the $13^{\text {th }}$ century are known from the churchyard Anyway, the gap is not sure and may be caused by the fragmentary nature of the source material. Site continuity and re-use after a longer time span can also be observed in Kanepi where the parish church was built beside the Iron Age and medieval cemetery in 1674 .

\section{CONCLUSIONS}

Archaeological grave finds from the churchyards of southern Estonia clearly indicate that churches were often built on pre-Christian cemeteries with cremation graves. Although most cremations, since being only represented by a few bone fragments, cannot be firmly dated, the few Iron Age jewellery finds refer to the final stage of prehistory. Even in the case of a time gap between the end of the Iron Age and the first data about the church or parish, there is reason to believe that the pre-Christian cemetery was used continuously until the church was founded - as a village burial ground with inhumations. In any case, the construction of churches on earlier local cemeteries shows the Estonians were actively involved in determining the places for churches at the time of Christianization.

Heiki Valk: On the Origins of Churches and Churchyards of Southern Estonia: the Evidence of Early Grave Finds Keywords: Medieval churches; Southern Estonia; ARCHAEOLOGY; CEMETERIES; CREMATION GRAVES; CHRISTIANIZATION 


\section{SUMMARY}

Data about the earliest history of medieval churches of southern Estonia are fragmentary, being limited to the first mentions of the parish, priest or congregation, or to mostly scanty historical information about the architecture. Some information can also be provided by archaeological grave finds, which often date back further than the first data about the churches.

The article presents a brief survey of the finds from the churchyards of southern Estonia, the area of medieval diocese of Tartu, from before ca. $1450 \mathrm{AD}$. The finds, mostly jewellery and fragments of cremated bones, show that churches were often built on top of old cemeteries from the Final Iron Age, whereby the pre-Christian jewellery items, mostly brooches, rings and bracelets, date mainly from the $11^{\text {th }}$ to the early $13^{\text {th }}$ centuries. If the cases in which the archaeological information is limited or non-existent are excluded, $60 \%$ of the rural churches of southern Estonia (9 out of 15) were built on pre-Christian cemeteries. The percentage may even be higher, since archaeological data for more than half of the churchyards is either missing or insufficient for drawing any conclusions. In the cases where major temporal gaps exist between the Final Iron Age finds and the first written or architectural data about the church, the cemetery probably functioned continuously as a village cemetery in the Christian period.

The pre-Christian origins of the cemeteries in the churchyards indicate that the local communities were actively involved in choosing the locations for the churches at the time of Christianization. Place continuity also shows that, despite the violent nature of Christianization, the natives of southern Estonia did not oppose having Christian sanctuaries built on pre-Christian cemeteries, and evidently, the continuous use of the former burial site was considered important.

\section{CV}

Heiki Valk (b. 1959) is archaeologist, working as a Senior Research Fellow at the Institute of History and Archaeology, University of Tartu, and the Head of the Archaeological Centre for Research and Infrastructure. His research deals with the Late Iron Age, Medieval Period and Early Modern Times, especially the culture of the native rural population of southern Estonia, with a focus on the cultural aspects of the archaeological record, and the relationship with folklore, ethnographic data, religion and cultural processes. His main fields of study are cemeteries, burial customs, sacred places and the distribution patterns of archaeological monuments. A special project is related to the chronology of the hill forts in southeast Estonia. Heiki Valk is the author of over 350 publications, the editor of several books, a member of the editorial boards of four journals, and the editor-in-chief of Tutulus, the popular annual journal of Estonian archaeology. 
